\title{
Cutting carbon-carbon composites by the diamond drills variable cyclic feed
}

\author{
Oleksandr Salenko ${ }^{1} \bullet$ Olga Chencheva ${ }^{2} \bullet$ Viktor Shchetynin $^{2} \bullet$ Valentina Gluchova $^{2} \bullet$ Evgeny Lashko $^{2} \bullet$ \\ Mohamed R.F. Budar ${ }^{2}$ \\ 1 - Igor Sikorsky Kyiv Polytechnic Institute, Kyiv, Ukraine; \\ 2 - Kremenchuk Mykhailo Ostrohradskyi National University Kremenchuk, Ukraine
}

\begin{abstract}
Purpose. The article presents an original solution to the actuality problem of increasing the efficiency of drilling composite materials of the carbon group with diamond drills through the use of a dynamic working feed. It is shown that the application of a cyclic lowfrequency load to a diamond drill makes it possible to increase the efficiency and quality of processing without destroying the composite.

Methodology. To solve the problems of determining the rational dynamic load of the drill during the operation, the approach of micro- and macroanalysis of the behavior of the processed material was used. The material itself was represented by an inhomogeneous finite medium, the properties of which are described using the concept of the initial structural element of the material.

Results. Based on the analysis of the behavior of the primary structural element, the stress state of the cutting zone in carbon composite materials was estimated, and it was shown that their processing using diamond ring drills is effective and efficient. Originality. The construction of models based on the primary structural element and the establishment of patterns of crack development in an inhomogeneous medium allowed us to obtain an expression for estimating the sizes of sludge particles formed during processing and determined rational processing conditions.

Practical value. The use of variable cyclic loading can significantly reduce the thickness of the destructive layer formed by the drill, as well as reduce the cutting force, especially during prolonged use. Since dust and sludge formation play an important role in drilling, further research should be aimed at establishing rational parameters of the working layer of the tool, the presence of cavities on it to remove microsludge and dust from the treatment zone.

Keywords: carbon composites, drilling, cutting, diamond tools
\end{abstract}

\section{Introduction}

Actuality of the work. In modern mechanical engineering, new composite materials with predetermined physical and mechanical properties are becoming more widespread, among which the fiber-laminated composite based on glass and carbon fibers account for greatest number [1]. Such materials are characterized by an entire complex of physical and mechanical properties demanded by high-tech production: strength, anisotropy, satisfactory heat resistance, low weight, high load capacity, etc.

Despite the fact that most of the products can be given the necessary shape at the stage of the workpiece preshaping, the need for finishing and bringing to the technical requirements is still relevant. Thus, the execution of different holes, ledges, window punching, edge processing - usually accompany any technological process and sometimes exceed the layout, saturation with adhesive, and shaping of the product as a whole [2, 3]. Another problem is the heterogeneous structure of the material and the significant difference in the mechanical properties of its components, which ultimately leads to a sharp deterioration of the edge quality when trying to processing similar materials with a conventional cutting tool [5].

That is why finding methods and ways to improve the efficiency of processing, ensuring its proper quality is the main focus of research by processing leading experts [6].

Obtaining holes in products from composites is a complex scientific and technical problem, the solution of which allows us to provide some requirements for the edges of the hole, reduce the thickness of the destructive layer and exclude the delamination of the material.

Of particular relevance is the task of making holes of medium diameter in the elements of the aviation and space systems, where damage to the product material is unacceptable.

$\begin{array}{lrl}\begin{array}{l}\text { O. Salenko } \\ \text { salenko2006@ukr.net }\end{array} & \begin{array}{l}\text { O. Chencheva } \\ \text { chenchevaolga@gmail.com }\end{array} & \begin{array}{l}\text { Viktor Shchetynin } \\ \text { schetynin_viktor@gmail.com }\end{array}\end{array}$


In articles [7], [8], [9], the authors note that the use of tubular drills with a diamond layer gives a good result, especially if the processing is carried out with loading of the cutting zone with harmonic or similar in nature force actions. As a rule, such loading is carried out by installing axial vibrators on the machine spindle, as well as by performing a stepwise axial feed of the drill. In this case, a periodic change in the stress state in the cutting zone prevents the adhesion of the particles of sludge formed during processing to the surface of the diamond layer, reduces the temperature, and increases the stability of the process.

For materials of the КИМФ-type, which are a carbon-carbon material 3-D structure, that is prone to cracking along the strands of reinforcing fibers, such treatment should be carried out with constant monitoring of the axial drilling force, withdrawing the drill from the treatment zone to remove sludge. Moreover, the effectivity of the method is quite low, and it is not possible to completely eliminate the marriage.

As such materials have a certain porosity, in our view, the improvement of processing efficiency is possible on the basis of taking into account the elastic-rheological properties of the material structure, describing its behavior under the action of cyclic axial force at the micro and macro levels. The expediency of such an approach is also evidenced by $[10]$.

The purpose of the work is to find a rational axial load for a diamond drill when processing materials of the КИМФ-type 3-D structure.

\section{Research method and result}

Effective processing of composites is achieved in the following ways:

1) by using cutting tools with a special cutting-edge profile [5];

2) by creating additional loads in the cutting zone, leading to the redistribution of stresses in the tool area and changing the direction of crack development;

3 ) changing the power load and the direction of movement of the cutting edge by involving activating motions (due to, for example, cyclic or impact feed).

The latter method has the simplest technical implementation, since it does not require the installation of additional mechanical elements or devices bringing additional energy to the area of influence; variable power load may be provided by appropriate movements of the tool itself.

Let's assume that the surface layer in the processed area is formed by the integrated action of the aggregate of abrasive grains, $3_{i}$ which carry out the spatial motion together with the base (tube) on which they are rigidly fixed (fig. 1).

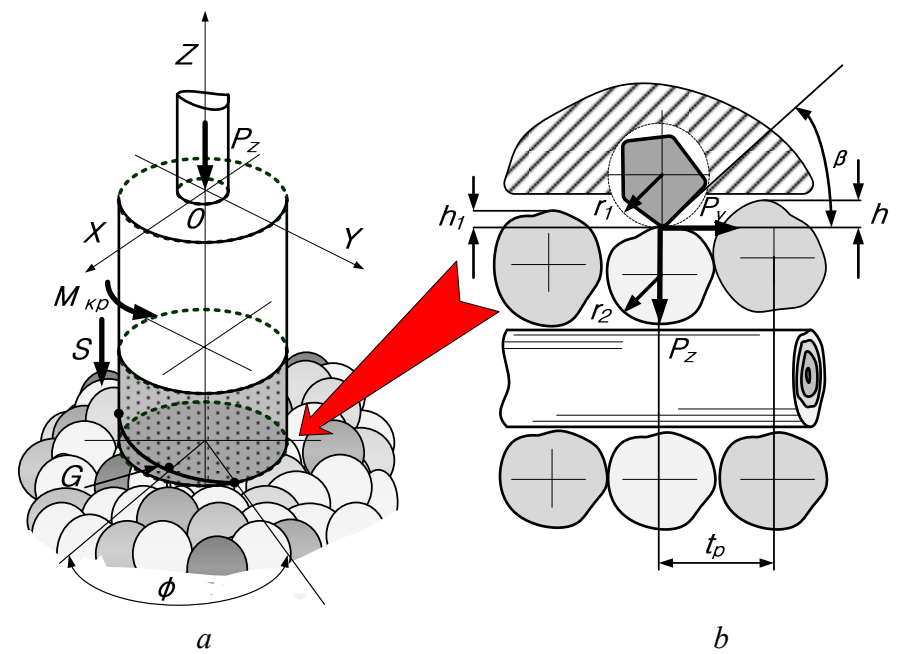

Fig. 1. Grain movement $(a)$ and scheme of its interaction $(b)$ with the processed surface

It is known [2], that the trajectory of movement of the latter will be conditioned by simultaneous rotational ( $\left.P_{1}\right)$ and reciprocating $\left(P_{2}\right)$ motions, and in general will form be segments of a helical line, the length of which corresponds to the presence of a cavity in the body of the composite.

The trajectory of grain motion is described by the following system of equations:

$$
\begin{gathered}
x=r \sin \phi \\
y=r \cos \phi, \\
z=\frac{s}{n} \phi
\end{gathered}
$$


where $r$ - the distance from the center of the drill to the considered grain (mm); $\phi$ - the angle of the drill rotation; $S$ feed $(\mathrm{mm} / \mathrm{min}) ; n$ - the frequency rotation, $\mathrm{rev} / \mathrm{min} ; x, y, z$ - the grain coordinates.

Let us accept a number of assumptions. Let the cutting surface look like an envelope of micro-grooves, described by the trajectory of grain movement, provided that they are contacted with the medium in the form of a processed halfspace.

Because carbon fiber has a number of cavities and caverns, the trajectories of grain movement will be intermittent; on the other hand, the geometric parameters of the tool abrasive layer will also be variable, since during the processing the emerging sludge will partially stick to the surface, altering the grain reach, and the variable cutting forces and high temperature in the interaction zone may cause grains to be broken off in bits.

The work tool forms the lateral and butt surfaces of the cut. For the butt surface erosion is maximum, since it is determined by the regular feed, and for the lateral surfaces - the minimum, and determines the surface roughness, with minimal fiber breakage.

\section{Micromechanics of the material}

To determine the length of the contact zone, we use the concept of the primary structural element of the composite (PSE). Let's assume that such an element is a cylindrical body with a diameter $d_{v}$, on the surface of which there is a layer $S_{p v}$ of the matrix, and layer $S_{p p}$ of the cavity (fig. 2).

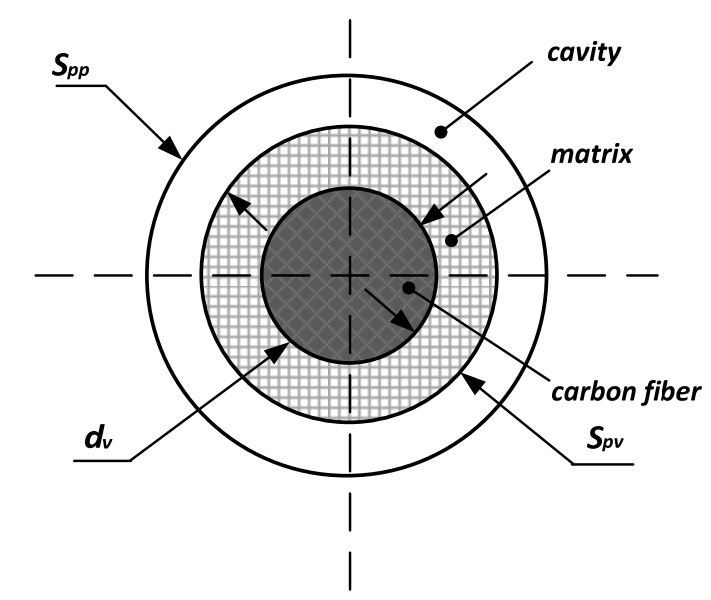

Fig. 2. Primary structural element (PSE) and its geometric characteristics

These layers can be characterized as: a cylindrical body with a diameter $d_{v}$ consisting of a set of carbon unidirectional fibers, an intermediate layer with a thickness $S_{p v}$ - a polymeric matrix, a layer $S_{p p}$ - a conditionally cavity layer with separate unidirectional oriented fibers.

Taking into accounts that for an infinitesimal parallelepiped of a deformable body, the components of the strain tensor are defined as:

$$
\varepsilon_{i j}=\frac{1}{2}\left(\frac{\partial u_{i}}{\partial v_{j}}+\frac{\partial u_{j}}{\partial x_{i}}\right), \quad i, j=1,2,3,
$$

where $u_{1}, u_{2}, u_{3}$ - projections of total displacements on the $x_{1}, x_{2}, x_{3}$ axes, then the Hooke law for an isotropic body will be:

$$
\begin{array}{ll}
\varepsilon_{11}=\frac{1}{E}\left[\sigma_{11}-\mu\left(\sigma_{22}+\sigma_{33}\right)\right], & j_{12}=\frac{\sigma_{12}}{G} ; \\
\varepsilon_{22}=\frac{1}{E}\left[\sigma_{22}-\mu\left(\sigma_{11}+\sigma_{33}\right)\right], & j_{23}=\frac{\sigma_{23}}{G} ; \\
\varepsilon_{33}=\frac{1}{E}\left[\sigma_{33}-\mu\left(\sigma_{22}+\sigma_{11}\right)\right], & j_{31}=\frac{\sigma_{31}}{G} .
\end{array}
$$

where $E$ - the material modulus of elasticity; $G$ - the shear modulus; $\mu$ - the Poisson's ratio, in this case $G=\frac{E}{2(1+\mu)}$.

In matrix form, Hooke's law will be written as $[\varepsilon]=[\psi][\sigma],[\psi]-$ the matrix of malleability, which determines the anisotropy of the properties of the body. 
Then for the matrix layers and conditionally cavity layer we obtain:

$$
[\psi]^{s_{p p}, s_{p v}}=\frac{1}{E}\left[\begin{array}{cccccc}
1 & -\mu & -\mu & 0 & 0 & 0 \\
-\mu & 1 & -\mu & 0 & 0 & 0 \\
-\mu & -\mu & 1 & 0 & 0 & 0 \\
0 & 0 & 0 & 2(1+\mu) & 0 & 0 \\
0 & 0 & 0 & 0 & 2(1+\mu) & 0 \\
0 & 0 & 0 & 0 & 0 & 2(1+\mu)
\end{array}\right] .
$$

And for the central nucleus (as orthotropic in the plane of force load action):

$$
[\psi]^{d_{v}}=\frac{1}{E}\left[\begin{array}{cccccc}
\frac{1}{E_{1}} & \frac{-\mu_{21}}{E_{2}} & \frac{-\mu_{31}}{E_{3}} & 0 & 0 & 0 \\
\frac{-\mu_{12}}{E_{1}} & \frac{1}{E_{2}} & \frac{-\mu_{32}}{E_{3}} & 0 & 0 & 0 \\
\frac{-\mu_{13}}{E_{1}} & \frac{-\mu_{23}}{E_{2}} & \frac{1}{E_{3}} & 0 & 0 & 0 \\
0 & 0 & 0 & \frac{1}{G_{12}} & 0 & 0 \\
0 & 0 & 0 & 0 & \frac{1}{G_{23}} & 0 \\
0 & 0 & 0 & 0 & 0 & \frac{1}{G_{31}}
\end{array}\right] .
$$

Here $E_{1}, E_{2}, E_{3}$ - modulus of elasticity relative to axes $x_{1}, x_{2}, x_{3}$ direction; $G_{1}, G_{2}, G_{3}-$ shear modulus in planes $\left(x_{1}, x_{2}\right),\left(x_{2}, x_{3}\right),\left(x_{3}, x_{1}\right), \mu_{i j}$ - Poisson ratios.

In its motion, the abrasive grain interacts with each PSE component. However, the working conditions of single grains on the butt and on the lateral surface are different.

The butt surface (grain $3_{3}$ ), which can be represented as a discontinuous surface layer at the macrolevel, with the step of cavities $t_{p}$, defined as $t_{p}=d_{v} / 2+s_{p p}+s_{v v}$, perceives the load from individual grains according to fig. $1, b$. Such an interaction can be represented as a jumping deepening of a conical indenter (diamond) under the axial action $P_{z}$ at the depth $h$, resulting in a cleavage with a cleavage angle $\beta$ after which a tangential force is applied $P_{y}$. Initially, the indenter slides along the generating line of cone upwards under the action of the constituent $t$ until the time moment when the force $P_{z}$ is sufficient to destroy the layer having depth $h_{1}$. The indenter overcomes the friction force between the chips and the base material. The sliding value of the indenter is determined by the radius of a single grain rounding. The interaction of the diamond grain with the surface of the material being processed at the ratio of depth of penetration $h$ to the radius of curvature of the cutting edge $\rho$ is less than 0,01 , is characterized by elastic stamping of the material, that is, the absence of its removal.

Under the action of normal force at the point of contact, the stresses are determined by the corresponding Hertz formulas, which, for the case of contact of the abrasive grain with rounding $r_{1}$ and $r_{2}$ radius of the rigid component (fiber bundle) according to the PSE concept will be: $\sigma_{k}=\frac{m_{p} P_{z}^{1 / 3} E^{2 / 3}}{r^{2 / 3}}$, where $m=1+\frac{r_{1}}{r_{2}}, E-$ the normalized modulus of elasticity, $E=\frac{2 E_{1} E_{2}}{E_{1}+E_{2}}, r-$ the normalized contact radius, $\frac{1}{r}=\frac{1}{r_{1}}+\frac{1}{r_{2}}$.

Since the fiber's strength margin is much higher than the stress created by the working grain, it can be assumed that the fibers that come to the surface and bound to the base matrix, will be destroyed by the mechanism of opening microcracks on the adhesion planes [7].

Then the moment $M_{f}$ of the applied external forces to the fibers will be: $M_{f}=\frac{3 l}{2 b} M_{0} \cos \omega t$.

The load application frequency will be determined by the geometric parameters of the PSE and will be: 


$$
\omega=\frac{\pi D}{\frac{d_{v}}{2}+s_{p p}+s_{p v}} n .
$$

In this case, the stresses at the base of the crack are determined by the dependence:

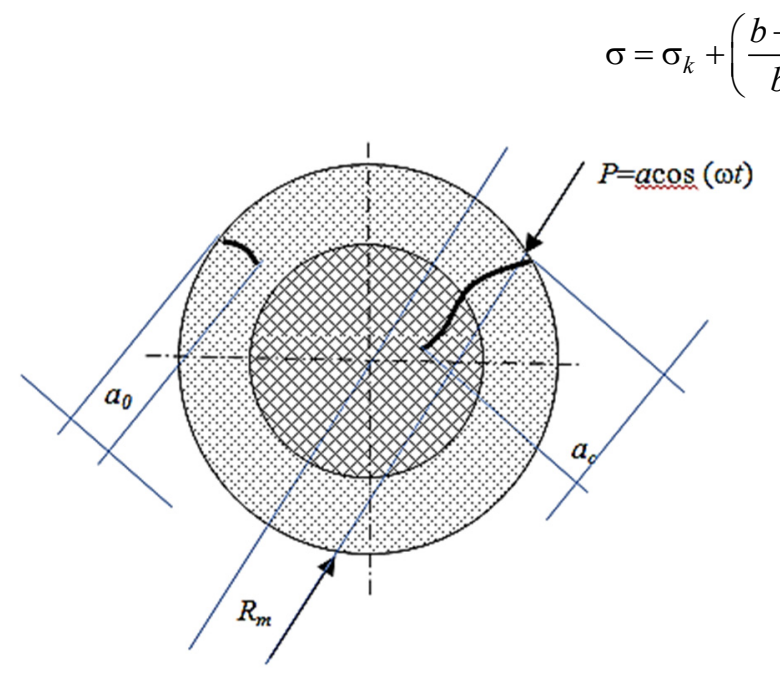

Fig. 3. The effect of a diamond grain on the recovered fiber bundle on the lateral surface of the hole

$$
\frac{d a}{d N}=\left(\frac{\Delta k}{\bar{c}}\right)^{n}
$$

where $M_{0}$ - the moment set by the previous equation, $b, l$ - the geometric parameters of the microcrack (fig. 3).

Then we have the value of the stress intensity factor $k=\sigma_{k}+\left(\frac{b-l}{b}\right) \frac{3 M_{f}}{2 b^{2}} \cos \omega t \sqrt{\pi a}, a-$ half the length of the open crack.

The rate of energy release associated with $k$ will be: $G=\frac{1-v^{2}}{E} A(V) k^{2}$, that under condition of the excess energy released transfer to the $(G-R)$, kinetic energy of the motion of the crack points, it will lead to a rapid increase in the length of the crack:

From the equation (8), the maximum crack length $a_{c}$ is determined by the number of loading cycles $N$ and the initial crack length at its inception $a_{0}$ :

$$
a_{c}=\frac{a_{0}}{\sqrt[n / 2-1]{1-\frac{\pi C D n t}{\left(\frac{d_{v}}{2}+s_{p p}+s_{p v}\right) K}}},
$$

where $C=a_{0}^{n / 2-1}\left(\frac{\sigma}{\rho}\right)^{n}\left(\frac{\rho}{\bar{c}}\right)^{n}, K=\frac{1}{\sqrt{\pi}(n / 2-1)}, a_{0}$ - the initial crack length; $\rho$ - material density; $n, \bar{c}-$ the material constants; $\sigma-$ the microstress.

\section{Macro mechanics of the material}

At the same time as the point load on the surface of the abrasive grain treatment, the cutting area is also perceived to have a forceful impact from contact with the tool body. The task of establishing a stress state is similar to the wellknown Hertz problem, but the representation of a material from the point of view of an elastic medium in the form of conjugated PSEs makes it possible to determine the displacement

$$
\begin{gathered}
U(t)=-\frac{(1-2 \mu)}{G} \frac{P_{z}(t)}{\left(D_{\max }-D_{\min }\right)^{2}} r, r>\frac{D_{\max }}{2} \\
H(t)=-\frac{(1-2 \mu)}{G} P_{z}(t) \frac{2}{\pi\left(D_{\max }-D_{\min }\right)}
\end{gathered} .
$$

Here $G$ - the shear modulus of the material being processed; $\mu$ - its Poisson's ratio; $\varepsilon$ - the volume deformation; $\Delta=\frac{d^{2}}{d r^{2}}+\frac{d}{r \partial r}+\frac{d^{2}}{d z^{2}}-$ the Laplace operator.

The processed half space is not dense. This requires consideration of its dynamic properties. According to the concept of PSE, the material appears to be a layered structure (in the form of some kind of conjugated fibers), which 
generally exhibits quasi-brittle properties, with cores of elastic-plasticity on the bonds, that is, in the nodes of the polymer matrix presence.

Then the material processed becomes a medium with a periodically varying structure that can be perceived as an elastic-plastic compound of concentrated masses (according to the Kelvin-Voigt processed body model), for which the stress distribution between the components (fiber bundle and matrix) corresponds to the equation:

$$
\sigma=E \varepsilon+\eta \frac{d \varepsilon}{d t}
$$

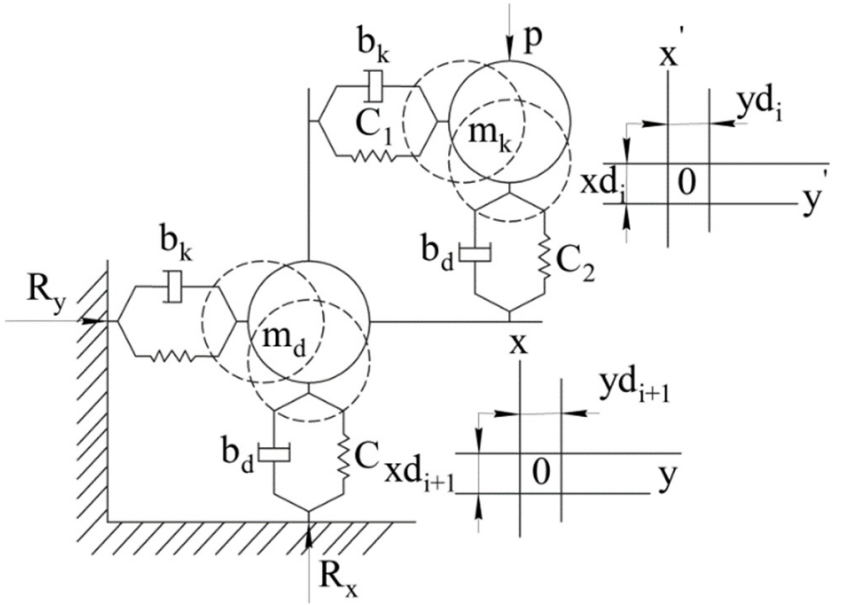

Fig. 4. The scheme of fibers stacking in the composite

where $E$ - the modulus of elasticity of the elastic component; $\eta$ - the viscosity of the component of the medium (matrix).

The deformations $\varepsilon$ will be $\varepsilon=\frac{\sigma}{E}\left(1-e^{\frac{t}{\tau}}\right)$ the behavior of the PSE components will be described by the corresponding differential equations. According to the scheme of fig. 4 the contact of the processed material with the tool and the bearing surface occurs with the occurrence of a cutting force $P$ on the top layer and the reaction of the support $\underline{R}_{\underline{x}}$ on the bottom in the vertical plane, and in the radial - as a balanced reaction to deformation of the surface with the drill. Then for the upper layer and for the normalized mass of the tool:

$$
\begin{gathered}
m_{k} \frac{d^{2} x_{k}}{d t^{2}}-b_{k} \frac{d x_{k}}{d t}-c_{1} x_{k}=P ; \\
m_{d} \frac{d^{2} x_{d}}{d t^{2}}-b_{d} \frac{d x_{d}}{d t}-c_{2} x_{d}=-R_{x} ; \\
m_{k} \frac{d^{2} y_{k}}{d t^{2}}-b_{k} \frac{d y_{k}}{d t}-c_{3} y_{k}=\sigma_{k} f_{k} ; \\
m_{d} \frac{d^{2} y_{d}}{d t^{2}}+b_{d} \frac{d y_{d}}{d t}+c_{4} y_{d}=R_{y} .
\end{gathered}
$$

In this case, $R_{x}=\frac{c_{1} c_{2}}{c_{1}+c_{2}}\left(x_{k}+x_{d}\right), R_{y}=\frac{c_{3} c_{4}}{c_{3}+c_{4}}\left(y_{k}+y_{d}\right)=\sigma_{k} f_{k}$ and the movement of the components in the vertical plane will occur in accordance with the cyclic action of the axial feed.

For the intermediate layers, we have the following equations system:

$$
\begin{aligned}
& m_{k(n-1)} \frac{d^{2} x_{k n-1}}{d t^{2}}-b_{k n-1} \frac{d x_{k n-1}}{d t}-c_{k n-1} x_{k n-1}+b_{k n} \frac{d x_{k}}{d t}+c_{k n} x_{k n}=0 ; \\
& m_{k(n-1)} \frac{d^{2} y_{k n-1}}{d t^{2}}-b_{k n-1} \frac{d y_{k n-1}}{d t}-c_{k n-1} y_{k n-1}+b_{k n} \frac{d y_{k}}{d t}+c_{k n} y_{k n}=0 .
\end{aligned}
$$

Based on the presented approach, we will analyze the КИМФ material of a 3D structure, the fiber bundles of which have a size of $1.75 \mathrm{~mm}$, regular weaving, pore sizes up to $0.75 \mathrm{~mm}$. The Electronic Microscope REM-106I and the TL-90 type profilometer was used to determine the grain reach value.

To perform the estimation of the expected size of the sludge particles by the obtained micro- and microelectronic photo of the samples, geometric parameters of the PSE taken into account (fig. 5, $a$ ). In another side, it is established that the particles of diamond protrude above the surface at a height of $0,08-0,68 \mathrm{~mm}$, so single cutting grain were established (fig. 5, $b$ ).

It is established that the carbon fiber bundle represented by the PSE nucleus has a diameter of $d_{v}$ 1,57-1,72 mm; the polymer matrix covers the bundle with a layer of $S_{p p} 0,35-0,55 \mathrm{~mm}$; the thickness of the intermediate layer with air cavities equals to $S_{p v} 0,18-0,22 \mathrm{~mm}$. 
Separate diamond grains with a fraction of $150 / 200 \mu \mathrm{m}$ is observed on the surface of the cutting edges of the tool (fig. 5, b) separate diamond grains with a fraction of $150 / 200 \mu \mathrm{m}$ is observed; the density of such grain's arrangement is $250-300 \mathrm{u} / \mathrm{cm}^{2}$.

The calculation of the expected size of the particles to be produced during the processing indicates (fig. 6) that in the sludge, the particles of the polymer matrix, the broken fibers and the conglomerates for which the cracks have developed to a critical size can be separated. This corresponds to the calculations obtained on the basis of equation (9).
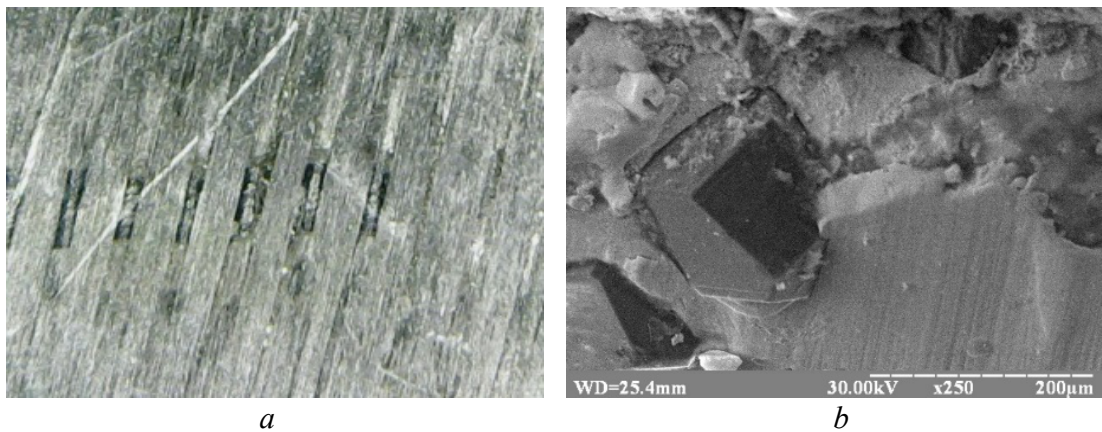

Fig. 5. Micro- and microelectronic photos of the carbon plastic structure and the surface of a diamond-coated tubular drill

From the equations $(6,7)$ it is easy to see that the characteristic particle size (for example, length $l_{z}$ or larger size) is due to:

1) Orientation of the reinforcing fibers relative to the applied force (since $E$ and $G$ components change, with changes in $\sigma$;

2) The size of the protruding particle of the abrasive grains (varies $l_{i}$ and $\sigma$ ), (fig. 3);

3) Frequency of variable axial load $n, N$ and, accordingly, $M_{f}$;

The stresses in the surface layer $\sigma_{0}$, caused by the force of the axial feed $P$.

The analysis of the results of the calculations proves that all the factors taken into account are valid, though having different degrees of influence. The most significant influence on the size of the sludge particles has a forceful effect on the material to be processed (fig. 4). It can be expected that an increase in the applied axial force will cause a corresponding increase in stresses at the contact surface and that individual fibers and their conglomerates will be cleft. From the diagram above (fig. 5), it can be seen that a stress exceeding $40 \mathrm{MPa}$ significantly increases the size of the sludge particles; and based on the physical model of surface formation with a single grain, an inference can be made that the roughness will increase on the surface.
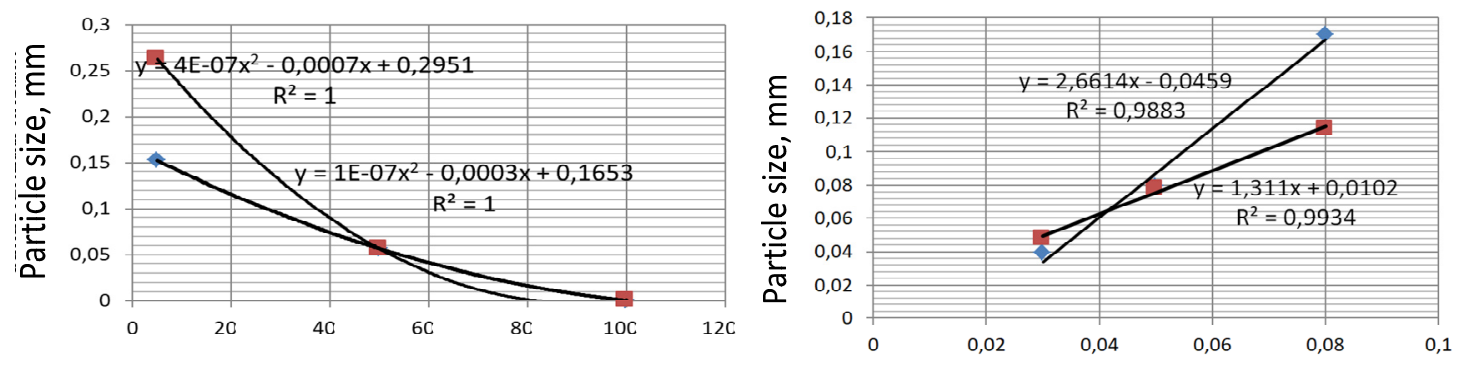

Frequency of loading with abrasive grain, $\mathrm{Hz}$

Removal of particles above the surface, $\mathrm{mm}$

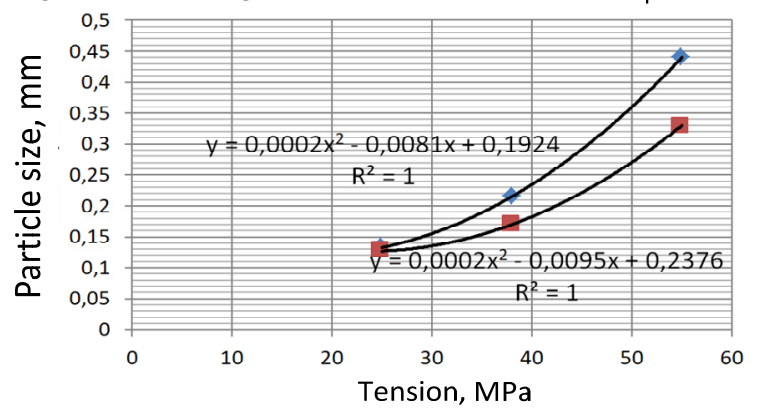

Fig. 6. Change in the expected size of the sludge particles depending on the conditions of interaction with the material, which is represented as an assumed PSE with different fiber orientation 
The influence of fiber orientation on the sludge fraction is not significant within the stresses of $15-40 \mathrm{MPa}$; orientation of fibers at angles approaching $\pi / 4$ leads to a decrease in the sludge fraction by $20 \ldots 35 \%$. The frequency of the working tool oscillation influences the size of the sludge particles significantly.

The use of low-frequency loading of the working body edge (in the frequency range 50-100 Hz) causes the appearance of significant sludge particles, the characteristic size of which can be expected at the level of $0,18-0,27 \mathrm{~mm}$. Since the frequency has the reverse effect, and the fiber bundles can significantly loosen without a matrix, such particles can be formed mainly from an adhesive.

The impact of the size of the console of the protruding part abrasive virtually linearly changes the expected sludge fraction: reduction in the reach value to $0,08 \mathrm{~mm}$ alters the microstress in the tip and affects the development of the microcrack mesh. Cracks begin to grow more actively, with particle size formation up to $0,08-0,12 \mathrm{~mm}$. In this case, the sludge contains separate fractions of cut carbon fibers (fig. 7,a).
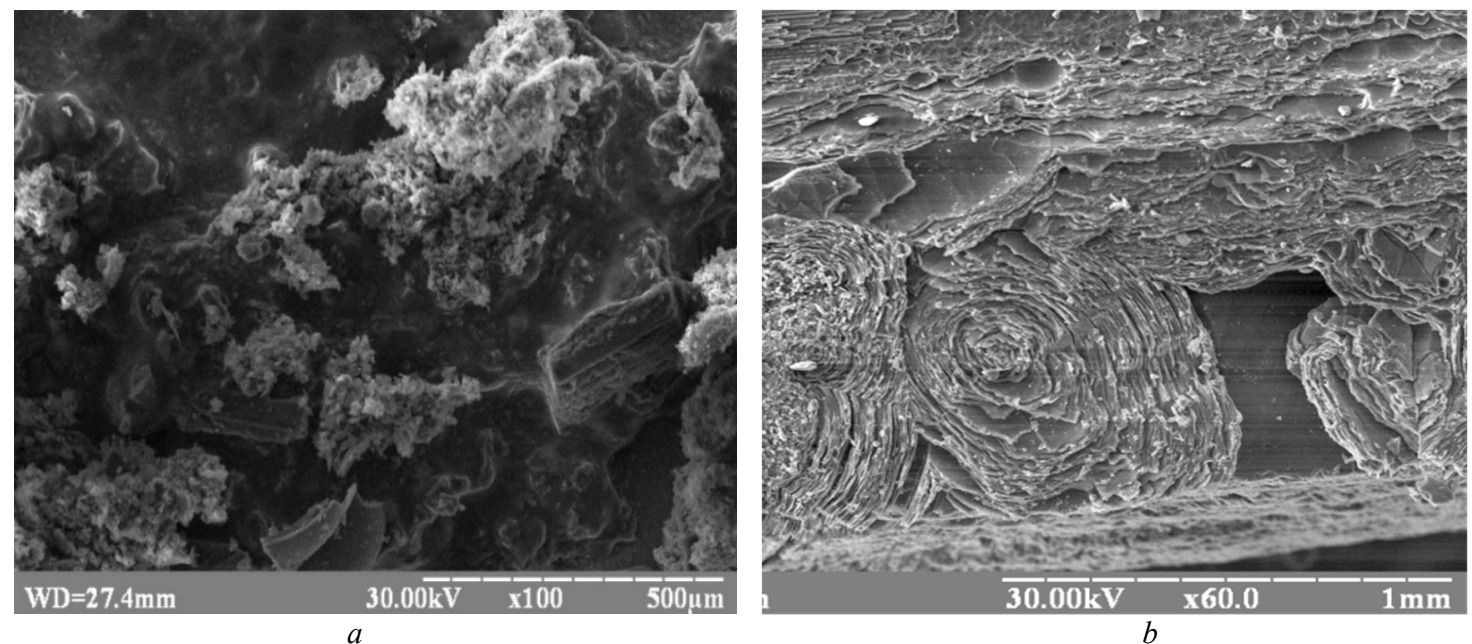

Fig. 7. Conglomerates of fibers and fine sludge from adhesive residue $a$ ) and naturals structure composite КИМФ $b$ ) particle.

Such result present in [9], where authors given information about influence cutting force on dimensions of

The presence of horizontal displacements between the coupled PSE on the layer following the plane of force application can be considered the stratification condition. Then PSE stresses values will be caused by their position with respect to crossing of the processed workpiece blank in accordance with fig. 8, whereas PSE parameters, will determine the level of stresses under, taking into account the structure hollowness (in fig. 8 the results of $\sigma_{i}$ change are provided as ratio of dynamic forces in elements to PSE contact area, which is determined by its geometry).

To determine the dynamic parameters of model $c$ and $b$, we take into account that under the action of the axial force, deformations occur on the contact plane, which are capable of causing adhesion disturbances in the intercontact space. In this case, the reinforcing fibers are excluded from the material, and the characteristics of $c$ and $b$ correspond to the properties of the polymer matrix.

The fiber exclusion length at destruction is determined:

$$
l_{0}=\frac{\sigma_{f b}-\sigma_{f \tau}}{13 \sqrt{b^{\prime}} E k_{\tau} \tau_{\tau}} l_{c},
$$

where $b^{\prime}$ - the crack depth; $l_{c}-$ the crack length; $E$ - modulus of elasticity; $\tau_{\tau}-$ tangential stresses; $k_{\tau}=0,3 \ldots 1,5$. The parameters indicated are determined by the micromechanics of the material, i.e. the characteristics of the interaction of grain with the surface.

Now, having an idea of the structure of the composite as an aggregate of PSE, the stresses on adjacent elements are found under the condition of greater (I) and lesser (II) hollowness (fig. 8).

Thus, if $U(t)$ exceeds the value of $y_{k}(t)$ with the occurrence of the corresponding stresses, which, taking into account the assumed assumptions with respect to PSE, will be:

$$
\tau=G\left(\frac{\partial U\left((t)-y_{k}(t)\right)}{\partial r}+\frac{\mu \varepsilon}{1-2 \mu}\right),
$$

there will be an internal delamination of the material outside the applied force area. 


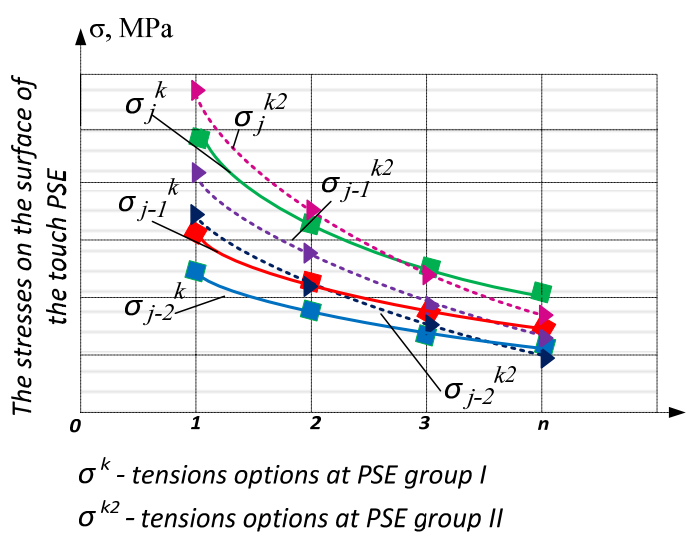

Fig. 8. Distribution of stresses in the PSE depending on their location relative to the applied cutting force Mathcad 12.0 software was used for this purpose
Let us solve the given system of equations with respect to $U(t)$ and $H(t)$ and establish the difference $P=\left(U(t)-y_{k}(t)\right)$, for different layers of material. Note, that the thickness of the layer formally corresponds to the size $h=d_{v}+2 s_{p p}+2 s_{p v}$.

Using the (10) and model (12), (13) take the harmonic law of force $F_{z}$ change as the acting load: $F_{z}=A \sin (\omega t)$.

The changes in the intersection stresses $\tau$ are shown in fig. 9. Each layer is indicated by a line $y 1-y 3$ in the scan for the time axis $t_{i}$.

In fig. 10, 11 the results of modeling the influence of the form of oscillations and the frequency of oscillations of the tool end on the magnitude and shape of the stresses arising on the first plane are provided. The impact is given as a single full-period effect at time $T, T=0,02 \mathrm{~s}$. The damping of the bonds is neglected, but the rheological properties of the composite components were taken into account.

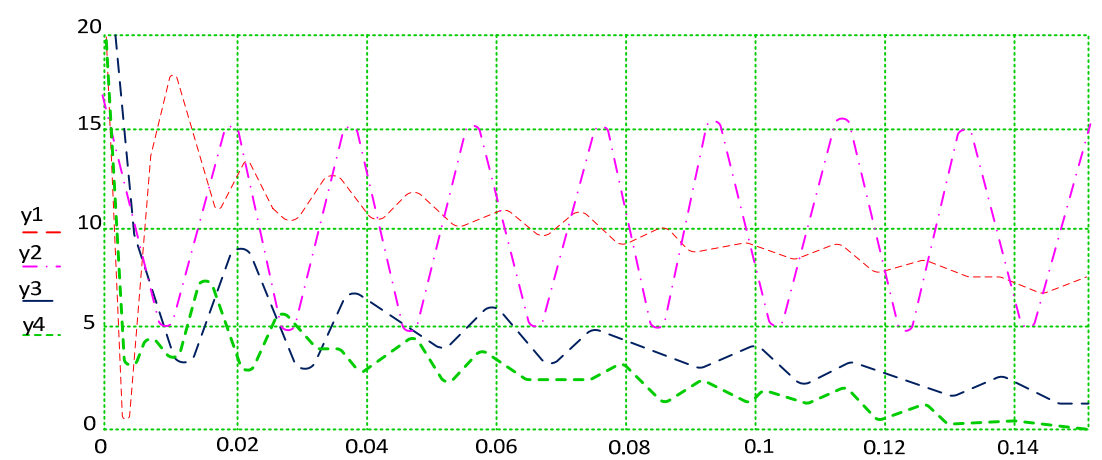

Fig. 9. The stresses that arise between the layers of composite material when applying periodic load (complies with the law $p z_{1}$ ): $y 1_{i}$-after the first layer; $y 2_{i}$-after the second; $y 3_{i}$-after the third one

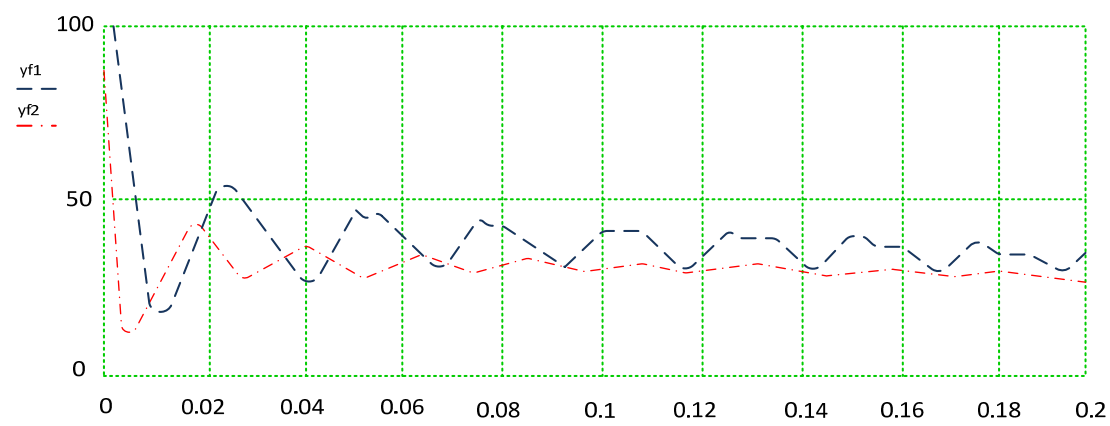

Fig. 10. Change of stresses at different forms of oscillation of the cutting tool end $y f_{1}$ - harmonic shape;

$y f_{2}$ - impact-dynamic

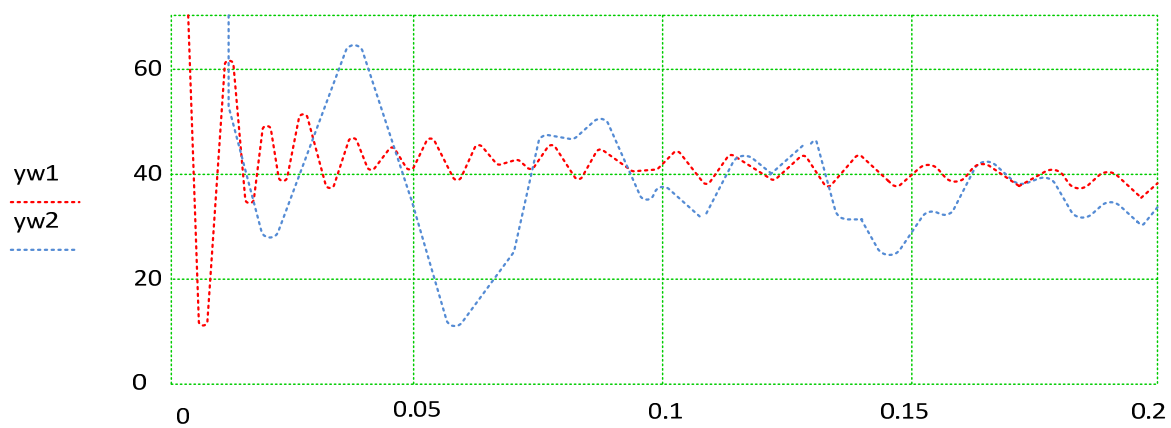

Fig. 11. Effect of oscillation frequency on the change of tangent stresses on the adhesion surface: increasing the frequency above $80 \mathrm{~Hz}$ leads to a significant decrease in the amplitude of the stresses arising 
The application of oscillations influences the stresses arising on the adhesion planes of the components of the composite significantly (reinforcing carbon fibers and polymer matrix). Thus, fig. 10 compares the forms of stress fluctuations on the first surface following the action plane when the shock-dynamic $\left(y f_{2}\right)$ and harmonic $\left(y f_{1}\right)$ effects are applied. Impact-dynamic impact corresponds to a sawtooth-like load with sharp increase in axial force and smooth unloading. In this case, it is obvious that the damping of such oscillations occurs slower, that is, it can be expected that the destruction of the material will occur in accordance with the scheme of low-cycle loading.

The tangential stresses decrease the penetration of the material, their phasal nature is changed, which generally corresponds to the accepted assumptions when modeling the PSE composite. The maximum stress values are observed on the first layer following plane of reinforcement fibers separation. At the expected level of stresses due to the quasistatic force $P_{z}$ action and stresses emerging on the contact plane at the level of $20 \mathrm{MPa}$, on the stress layer following the surface, will reach $15 \mathrm{MPa}$. At the same time, increasing the frequency of the tool end oscillations over $80 \mathrm{~Hz}$ leads to a decrease in the amplitude of stresses in the interlayer intervals (fig. 11) from almost $40 \mathrm{MPa}$ (at $40-50 \mathrm{~Hz}$ ) to $10 \mathrm{MPa}$ (at $90 \mathrm{~Hz}$ ).

The distortion of the oscillation shape is due to the dissipative component and the nonlinearity taken into account, which is related to the exclusion of fibers at stresses exceeding $30 \mathrm{MPa}$ (fig. 10, 11). The above studies allow us to draw a number of important conclusions. The 3-D structure of the material, the presence of pores in it, has a significant effect on the process of stress redistribution upon application of a varying axial force. In this case, the porosity of the material significantly changes its rheological properties, and, consequently, the level of stresses arising during the vibrational regime: with an increase in the vibrational frequency above $80 \mathrm{~Hz}$, the differences in peak stresses sharply decrease for the analyzed structure. Therefore, in order to increase the efficiency of drilling KIMF composites, the frequency and shape of vibrations of the working tool should be clearly related to its structure, in particular, to the shape and size of pores.

From the above results, it becomes obvious that the most appropriate load for drilling is a cyclic-variable load, which allows the highest quality of the hole. Experimental equipment and diagrams are shown in fig. 12-13. This diagram gives the change in controlled parameters - the depth of destruction $(R)$, surface roughness by parameter $R a$ depending on the depth of the drill $h$.

To visualize the redistribution of stresses between fiber bundles (layered in layers), a Solid Works was used in which composite models were previously created in accordance with the scheme columns 2 of table 1

The compare some results of processing with cyclic feed are shown in table 1, were we can see real structure of surfaces cutting and models of stress diagram. Results of simulations present in column 3, and microelectronic photo of surface - in columns 4 .
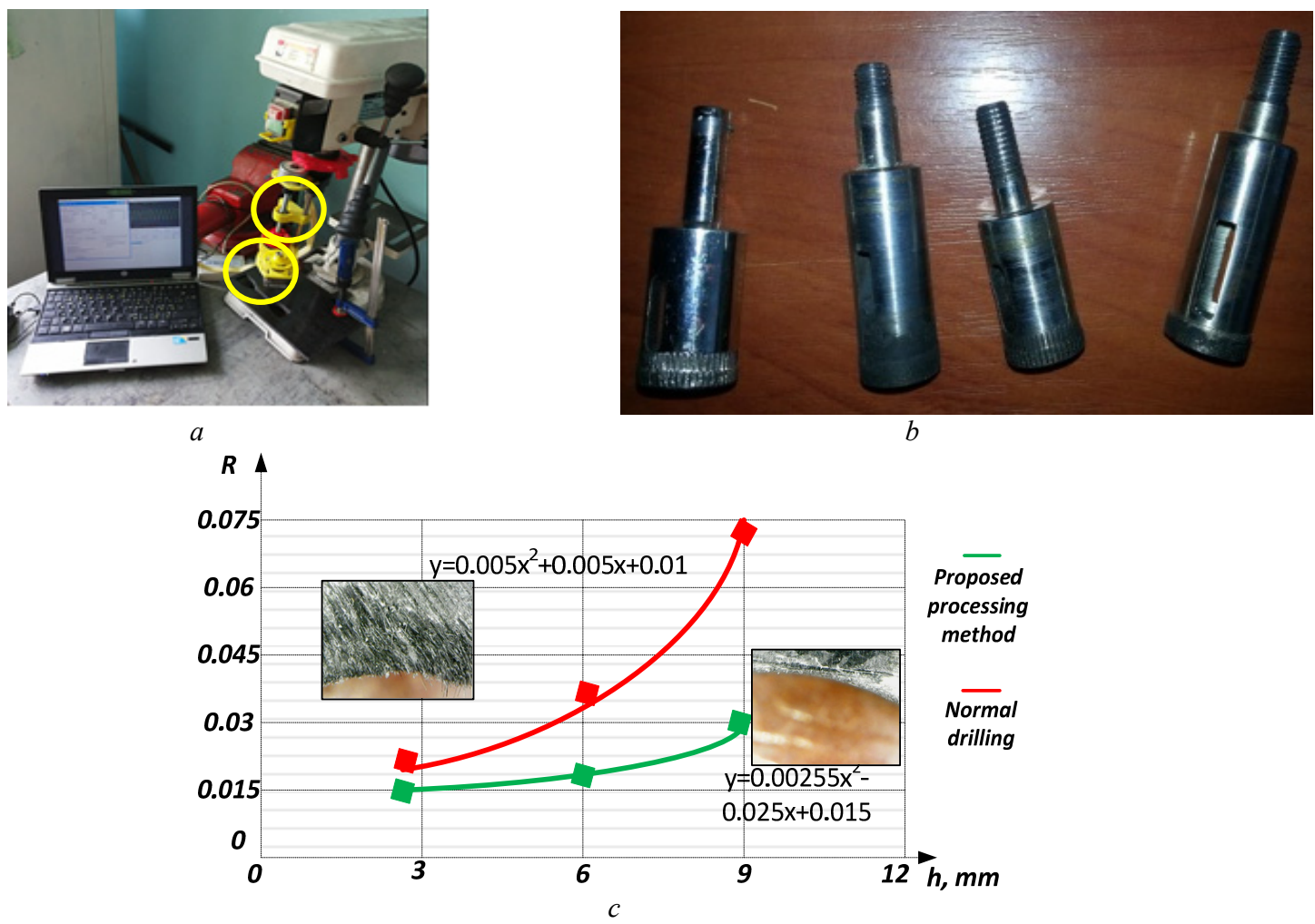

Fig. 12. Experimental equipment $(a)$, ring drills $(b)$ and the results of surface layer quality studies (destruction level $R$ ) after processing $(c)$ depending on the depth of the drill $h$ 


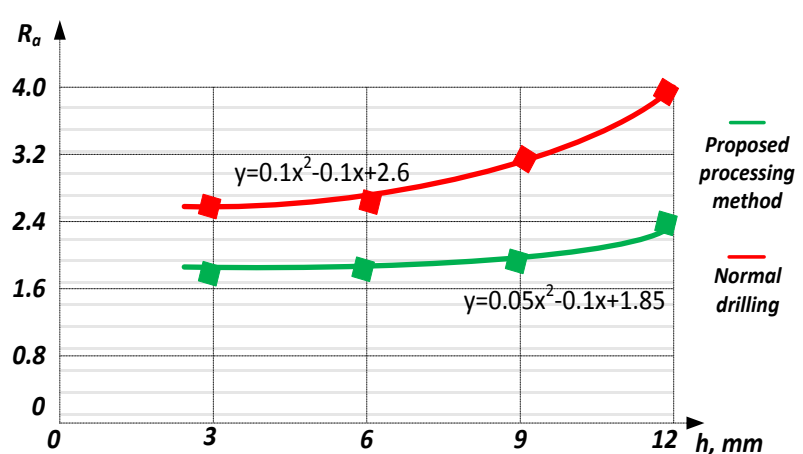

Fig. 13. Results of surface layer roughness $\left(R_{a}\right)$ studies after processing depending on the depth of the drill $h$. Next diagram compares the effort of axial feeds in normal mode and proposal mode (fig.14)

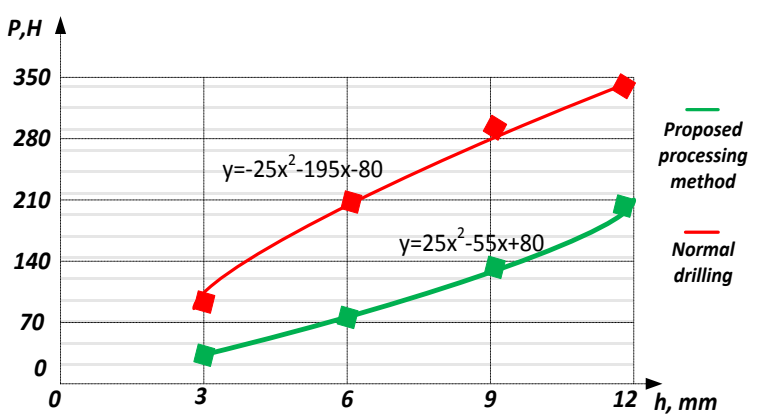

Fig. 14. Results of drilling effort $(P)$ studies depending on the depth of the drill $h$

This is consistent with the results presented in [12]. When modeling, it was taken into account that the dynamic properties of the material are described by equations $(12,13)$, while their coefficients were determined on the basis of $(2-5)$.

Table 1

\section{Surface quality depending lows of changing force}

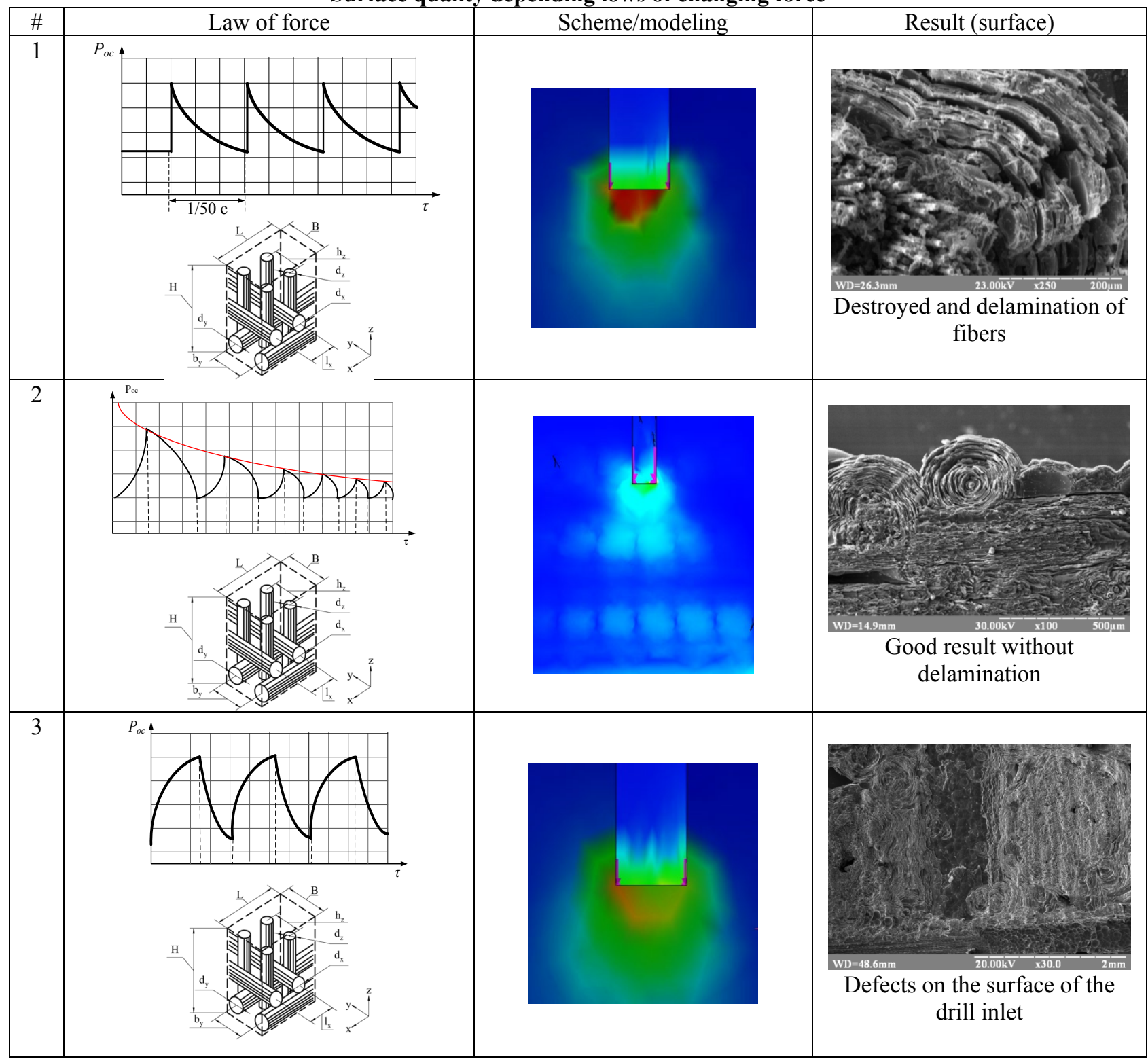


The stress state of the material from the action of the end of the drill was set according to (10), and the condition for the violation of adhesion between the fibers of the composite was set by equation 11. The adhesion failure itself was modeled by excluding a fiber of length (14) from the model when condition 15 was reached. Visualization was carried out using the Solid Works program.

Consequently, the material should be processed in a cyclically variable feed, but provided that there is no impact on the cutting zone in finishing moment.

Overlapping of the corresponding vibrations on the working tool (due to cyclic linear feed) greatly increases the drilling efficiency. To provide this movement (supply with oscillatory displacement of the ends), a technical solution is proposed for a power drive with connected electric machines [4].

Determination conditions of cutting carbon-carbon composites is a next step in study such processes by the diamond drills variable cyclic feed.

Thus, the use of the proposed approach allows us to take into account the rheological properties of the material in the calculations and increase the efficiency of using diamond ring drills for processing holes in blanks made of KIMF carbon-carbon material with a cyclic quasi-harmonic feed, the modes of which for material with bundle diameters of $1.75 \mathrm{~mm}$ and pores $0.75 \mathrm{~mm}$ are: frequency up $80 \mathrm{~Hz}$, the amplitude of the axial feed - up to $20 \%$ of its actual value, maximum stress on the layer of cutting - less $40 \mathrm{MPa}$.

\section{Conclusions}

As a consequence of the performed set of theoretical and experimental research, the stress state of the cutting zone in composite materials based on carbon fibers has been evaluated and it is proved that their processing with ring diamond-coated drills is reasonable and effective. The use of a cyclic linear feeder allows significantly reducing the thickness of the destructive layer and reducing the cutting force, requiring further research on the issue of rational geometric dimensions of the tool end, the presence of cavity elements on it to remove the microstrip from the processing area.

It is also proven that the proposed design of a power head with coupled electric machines to provide rotary and feed motion in coaxial execution is a promising technical solution that can be successfully implemented in both manual tools and automated processing programmed control systems.

\section{References}

1. Marshall I. H. Design with advanced composite materials. In Phillips, L.N. (ed.), The Design Counsil, Berlin, Heidelberg, London, 1989. - $365 \mathrm{p}$.

2. Konig W., Wulf Ch., Grab P. and Willerscheid H. Machining of fibre reinforced plastics - Annals of the CIRP. - 1985. Vol. 34, No.2. - P. 537-548. https://doi.org/10.1016/S0007-8506(07)60186-3

3. Sheikh-Ahmad J., Davim Paulo J. Cutting And Machining of polymer Composites, Wiley Encyclopedia of Composites, 2012.

4. Drilling of Carbon Fibre Reinforced Polymer Materials - A Review. International Journal of Mechanical and Production Engeneering, Research and development. - 2018. - Vol. 8, No.2. P. 157-166. https://doi.org/10.24247/ijmperdapr201817

5. Ma F.J., Zhu X.L., Kang R.K., Dong Z.G., Zou S.Q. Study on the subsurface damages of glass fiberreinforced composites. Adv Mater Res. - 2013. - Vol. 797. - P. 691-695.

6. Tsao C.C., Hocheng H., Chen Y.C. Delamination reduction in drilling composite materials by active backup force, CIRP Annals - Manufacturing Technology. - 2012. - Vol. 61. No.1. P. 91-94. https://doi.org/10.1016/j.cirp.2012.03.036

7. Sheikh-Ahmad J., Davim Paulo J. Cutting And Machining of polymer Composites, Wiley Encyclopedia of Composites, 2012.

8. Xu J, Li Xi, Chen M, El Mansory M, Ren F. Study of the drilling process of high-strength carbon composite materials using specialized drills. Int J Adv Manuf Technol. - 2019. - Vol. 103, No.9. - P. 3425-3442.

9. Xu J, Li Si, Dang J, El Mansory M, Ren F. Study of drilling high-strength carbon fiber laminates: friction temperature and cutting temperature. Materials. - 2018. - Vol. 11, No.12. P. 2366. https://doi.org/10.3390/ma11122366

10. Kirichenko A. Improving the quality of abrasive cutting carbon-carbon composites through rational conditions of dynamic contact / A. Kirichenko, Metaq Al Ibrahim, V. Schetinin, O. Chencheva // Transactions of Kremenchuk Mykhailo Ostrohradskyi National University. - 2018. - Vol. 5, No.112. - P. 94-102.

11. Wang H., Sun J. and dr. "Evaluation of cutting force and cutting temperature in milling carbon fiber-reinforced polymer composites", International Journal of Advanced Manufacturing Technologies. - 2015. - Vol. 85. pp. 9-12.

12. Salenko A. About expediency of the use of combined rotating electric cars in power heads of new technological equipment" / A. Salenko, O. Chencheva. - Transactions of Kremenchuk Mykhailo Ostrohradskyi National University. - 2014. - Vol. 4, No.87. - P. 111-119.

13. Salenko Alexandr. Forming a defective surface layer when cutting parts made from carbon-carbon and carbon-polymeric composites / Alexandr Salenko, Olga Chencheva, Evgeny Lashko, Viktor Shchetynin, Sergey Klimenko, Alexandr Samusenko, Alexandr Potapov, Irina Gusarova // Eastern-european journal of enterprise technologies. Engineering technological systems. - 2018. - Vol. 4, No.1 (94). - P. 62-73. 
14. Wang H., Sun J. and dr. "Evaluation of cutting force and cutting temperature in milling carbon fiber-reinforced polymer composites", International Journal of Advanced Manufacturing Technologies. - 2015. - Vol. 85, P. 9-12.

15. Bobyr, M., Altenbach, H. \& Khalimon, O. "On the application of the continuum damage mechanics to multi-axial low-cyclic damage", Archive of Applied Mechanics. - 2015. - Vol. 85, No.4, P. 455-468. https://doi.org/10.1007/s00419-014-0922-2

\title{
Обработка карбон-карбоновых композитов алмазными сверлами с изменяемой циклической подачей
}

\author{
Александр Саленко, Ольга Ченчевая, Виктор Щетинин, Валентина Глухова, Евгений Лашко, Мохамед Будар
}

Аннотация. В статье представлено оригинальное решение актуальной проблемы повышения эффективности сверления композиционных материалов углеродной группы алмазными сверлами за счет использования динамической рабочей подачи. Показано, что приложение ииклической низкочастотной нагрузки $к$ алмазному сверлу позволяет повысить эффективность и качество обработки, не разрушая композит.

Для решения задач определения раџиоанльной динамической нагрузки сверла при выполнении операции использовался подход микро- и макроанализа поведения обрабатываемого материала. Сам материал представляли неоднородной конечной средой, свойства которой описаны с применением понятия начального структурного элемента материала.

На основе анализа поведения начального структурного элемента было оченено напряженное состояние зоны резания 6 углеродных композиционных материалах, при этом показано, что их обработка с помощью алмазных кольцевых сверл является действенной и эффективной.

Построение моделей на основе начального структурного элемента и установление закономерностей развития трещин в неоднородной среде позволила получить выражение для оценки размеров образующихся в прочессе обработки частии илама и установить рациональные условия обработки.

Применение изменяемого ииклического нагружения позволяет значительно уменьшить толщину разрушающего слоя, формируемого самим свердом, а также уменьшить силу резания, особенно при длительной работе. Поскольку пыле- $и$ иламообразование играют важную роль при сверлении, дальнейшие исследования должны быть направлены на установление рациональных параметров рабочего слоя инструмента, наличия на нем плостей для удаления микрошлама и пыли из зоны обработки.

Ключевые слова: углеродные композиты, сверление, резка, алмазный инструмент

\section{Обробка карбон-карбонових композитів алмазними свердлами зі змінною циклічною подачею}

\author{
Олександр Саленко, Ольга Ченчева, Віктор Щетинін, Валентина Глухова, Свгеній Лашко, Мохамед Будар
}

Аннотация. У статті представлено оригінальне вирімення актуальної проблеми підвищення ефективності свердління композиційних матеріалів вуглецевої групи алмазними свердлами за рахунок використання динамічної робочої подачі. Показано, що накладання ииклічного низькочастотного навантаження алмазного свердла дозволяє підвищити ефективність і якість обробки, без деструкції та руйнування композиту. На основі аналізу поведінки початкового структурного елементу було оцінено напружений стан зони різання у вуглецевих композиційних матеріалах, при цьому показано, щуо їх обробка за допомогою алмазних кільцевих свердел є дієвою і ефективною. Застосування змінного ијикічного навантаження дозволяє значно зменшити товщину еструктованого шару, який формується самим свердлом, а також зменшити силу різання, особливо при тривалій роботі. Оскільки пило- та шламоутворення грають важливу роль під час свердління, подальші дослідження повинні бути спрямовані на встановлення раціональних параметрів робочого шару інструменту, наявності на ньому порожнин для видалення мікрошламу і пилу за зону обробки.

Ключові слова: вуглецеві композити, свердлування, різання, алмазний інструмент

References

1. Marshall, I. H. (1989), Dizayn s ispol'zovaniyem sovremennykh kompozitnykh materialov Dizayn s ispol'zovaniyem sovremennykh kompozitnykh materialov [Design with advanced composite materials], in L.N.Phillips (ed.), The Design Counsil, Berlin, Heidelberg, London.

2. Konig, W., Wulf, Ch., Grab, P. and Willerscheid, H. (1985), Machining of fibre reinforced plastics, Annals of the CIRP, vol. 34, no. 2, pp. 537-548, https://doi.org/10.1016/S0007-8506(07)60186-3

3. Sheikh-Ahmad, J., Davim, Paulo J. (2012), "Cutting And Machining of polymer Composites", Wiley Encyclopedia of Composites.

4. Bellam, Venkatesh and Sikarwar, Rahul S. (2018), "Drilling of Carbon Fibre Reinforced Polymer Materials - A Review", International Journal of Mechanical and Production Engeneering, Research and development, vol. 8, no. 2. pp. 157 - 166, https://doi.org/10.24247/ijmperdapr201817

5. Ma, F.J., Zhu, X.L., Kang, R.K., Dong, Z.G. and Zou, S.Q. (2013), "Study on the subsurface damages of glass fiberreinforced composites", Adv Mater Res, vol. 797, pp. 691-695. 
6. Tsao, C.C., Hocheng, H. and Chen, Y.C. (2012), "Delamination reduction in drilling composite materials by active backup force", CIRP Annals - Manufacturing Technology, vol. 61, no.1, pp. 91-94, https://doi.org/10.1016/j.cirp.2012.03.036

7. Sheikh-Ahmad, J. and Davim, Paulo J. (2012), "Cutting And Machining of polymer Composites", Wiley Encyclopedia of Composites.

8. Xu, J., Li, Xi., Chen, M., Mansory, M. and Ren, F. (2019), "Study of the drilling process of high-strength carbon composite materials using specialized drills", Int J Adv Manuf Technol, vol. 103, no. 9, pp. 3425-3442.

9. Xu, J., Li, Si., Dang, J., Mansory, M. and Ren. F. (2018), "Study of drilling high-strength carbon fiber laminates: friction temperature and cutting temperature", Materials, vol. 11, no. 12, pp. 2366, https://doi.org/10.3390/ma11122366

10. Kirichenko, A., Ibrahim, Metaq Al., Schetinin, V. and Chencheva, O. (2018), "Improving the quality of abrasive cutting carbon-carbon composites through rational conditions of dynamic contact", Transactions of Kremenchuk Mykhailo Ostrohradskyi National University, vol. 5, no. 112, pp. 94-102.

11. Wang, H., Sun, J. and dr. (2015), "Evaluation of cutting force and cutting temperature in milling carbon fiber-reinforced polymer composites", International Journal of Advanced Manufacturing Technologies, vol. 85, pp. 9-12.

12. Salenko, A. and Chencheva, O. (2014), "About expediency of the use of combined rotating electric cars in power heads of new technological equipment”, Transactions of Kremenchuk Mykhailo Ostrohradskyi National University, vol. 4, no. 87, pp. 111-119.

13. Salenko, Alexandr, Chencheva, Olga, Lashko, Evgeny, Shchetynin, Viktor, Klimenko, Sergey Samusenko, Alexandr Potapov, Alexandr and Gusarova Irina (2018), "Forming a defective surface layer when cutting parts made from carboncarbon and carbon-polymeric composites", Eastern-european journal of enterprise technologies. Engineering technological systems, vol. 4, no. 1 (94), pp. 62-73.

14. Wang, H., Sun, J. and dr. (2015), "Evaluation of cutting force and cutting temperature in milling carbon fiber-reinforced polymer composites", International Journal of Advanced Manufacturing Technologies, vol. 85, pp. 9-12.

15. Bobyr, M., Altenbach, H. and Khalimon, O. (2015), "On the application of the continuum damage mechanics to multi-axial low-cyclic damage", Archive of Applied Mechanics, vol. 85, no. 4, pp. 455-468. https://doi.org/10.1007/s00419-014-0922-2 